\title{
Effect of Cadmium and Copper Exposure on Growth, Secondary Metabolites and Antioxidant Activity in the Medicinal Plant Sambung Nyawa (Gynura procumbens (Lour.) Merr)
}

\author{
Mohd Hafiz Ibrahim ${ }^{1, *}$, Yap Chee Kong ${ }^{1}$ and Nurul Amalina Mohd Zain ${ }^{2, *}$ \\ 1 Department of Biology, Faculty of Science, Universiti Putra Malaysia, UPM Serdang, \\ Selangor Darul Ehsan 43400, Malaysia; yapchee@upm.edu.my \\ 2 Department of Biology, Institute of Biological Science, Faculty of Science, University Malaya, \\ Kuala Lumpur 50603, Malaysia \\ * Correspondence: mhafiz_ibrahim@upm.edu.my (M.H.I.); amalina86@um.edu.my (N.A.M.Z.); \\ Tel.: +60-11-1566-3969 (M.H.I.)
}

Received: 4 September 2017; Accepted: 26 September 2017; Published: 12 October 2017

\begin{abstract}
A randomized complete block (RCBD) study was designed to investigate the effects of cadmium $(\mathrm{Cd})$ and copper $(\mathrm{Cu})$ on the growth, bioaccumulation of the two heavy metals, metabolite content and antibacterial activities in Gyanura procumbens (Lour.) Merr. Nine treatments including (1) control (no Cd and Cu); (2) Cd $2=$ cadmium $2 \mathrm{mg} / \mathrm{L}$; (3) Cd 4 = cadmium $4 \mathrm{mg} / \mathrm{L}$; (4) Cu $70=$ copper $70 \mathrm{mg} / \mathrm{L}$; (5) Cu $140=$ copper $140 \mathrm{mg} / \mathrm{L}$ ); (6) Cd $2+\mathrm{Cu} 70$ = cadmium $2 \mathrm{mg} / \mathrm{L}+$ copper $70 \mathrm{mg} / \mathrm{L}) ;(7) \mathrm{Cd} 2+\mathrm{Cu} 140=$ cadmium $2 \mathrm{mg} / \mathrm{L}+$ copper $70 \mathrm{mg} / \mathrm{L}) ;(8) \mathrm{Cd} 4+\mathrm{Cu} 70=$ cadmium $4 \mathrm{mg} / \mathrm{L}+$ copper $70 \mathrm{mg} / \mathrm{L}$ and (9) $\mathrm{Cd} 4+\mathrm{Cu} 140=$ cadmium $4 \mathrm{mg} / \mathrm{L}+$ copper $140 \mathrm{mg} / \mathrm{L}$ ) were evaluated in this experiment. It was found that the growth parameters (plant dry weight, total leaf area and basal diameter) were reduced with the exposure to increased concentrations of $\mathrm{Cd}$ and $\mathrm{Cu}$ and further decreased under interaction between $\mathrm{Cd}$ and $\mathrm{Cu}$. Production of total phenolics, flavonoids and saponin was observed to be reduced under combined $\mathrm{Cd}$ and $\mathrm{Cu}$ treatment. The reduction in the production of plant secondary metabolites might be due to lower phenyl alanine lyase (PAL) activity under these conditions. Due to that, the 1,1-diphenyl-2-picrylhydrazyl (DPPH), ferric reducing antioxidant potential (FRAP) and antibacterial activities was also found to be reduced by the combined treatments. The current experiments show that the medicinal properties of G. procumbens are reduced by cadmium and copper contamination. The accumulation of heavy metal also was found to be higher than the safety level recommended by the WHO in the single and combined treatments of $\mathrm{Cd}$ and $\mathrm{Cu}$. These results indicate that exposure of G. procumbens to $\mathrm{Cd}$ and $\mathrm{Cu}$ contaminated soil may potentially harm consumers due to bioaccumulation of metals and reduced efficacy of the herbal product.
\end{abstract}

Keywords: medicinal plants; heavy metal contamination; secondary metabolites; antibacterial activity

\section{Introduction}

Due to human activities, the content of heavy metals in soils keeps increasing due to increased industrialization, energy production, agriculture activities and municipal waste production [1]. This has led to an accumulation of non-essential and toxic heavy metals such as aluminium (Al), arsenic (As), cadmium (Cd), manganese (Mn) and chromium $(\mathrm{Cr})$ in Malaysian agricultural soils. Although these trace elements are important for plant growth (essential micronutrients), others have no metabolic role and may adversely affect plant growth and metabolism [2]. High concentrations of these metals might cause growth inhibition and even plant death. These heavy metals have the 
capability to be transferred and accumulated in plants, animals and humans [3]. Moreover, these heavy metals have long term persistence in the human body, which might cause hazardous health issues to humans. There are several factors influencing the concentrations of these metals in plants such as the plant species, microclimate conditions, environmental pollution and other factors [4]. Among these heavy metals, cadmium $\left(\mathrm{Cd}^{2+}\right)$ and copper $\left(\mathrm{Cu}^{2+)}\right.$ are known to delay plant growth and cause the formation of reactive oxygen species and thus affect membrane function and permeability [5].

Cadmium is one of the heavy metals that has a high impact on environment degradation. The contamination with this heavy metal is due to the manufacture of diverse products such as batteries, chipsets, pigments, television receivers, and semiconductors [6]. Cadmium is easily taken up by plant roots and transported to the aerial parts, thus entering the food chain and causing health problems in animals and humans. Cadmium can easily bind to sulfated groups, e.g., as found in metalloproteins and metalloenzymes, thereby degrading their functions [7]. Cadmium also does not have any benefit or nutritional value for plants, and excessive exposure to this heavy metal can cause toxicity indicated by altered chloroplast ultrastructure, chlorosis-stunted plant growth, reduction in photosynthesis, degradation of enzymes involved in $\mathrm{CO}_{2}$ fixation, lipid peroxidation and disturbance of the nitrogen $(\mathrm{N})$ and sulfur (S) metabolism [8].

Copper is an essential element for plant growth and development, but because only a small amount is needed, it is classified as a micronutrient. The amount of $\mathrm{Cu}$ available to plants varies widely by soils. Available Cu can vary from 1 to 200 ppm (parts per million) in both mineral and organic soils as a function of soil $\mathrm{pH}$ and soil texture [9]. Several sources of $\mathrm{Cu}$ contamination exist in the environment, including industrial and domestic waste, agricultural practices, copper marine drainage, copper-based pesticides, and antifouling paints. This metal is a structural element in regulatory proteins, photosynthetic electron transport, mitochondrial respiration, oxidative stress, cell wall metabolism, transcription, protein trafficking, and hormone signalling [10]. However, in excess, it can inhibit growth and impair important cellular processes like photosynthetic electron transport, photosynthesis, and respiration. Membrane transport systems seem to be a target of this metal, playing a central role in its toxicity processes [11].

Exposure to heavy metals leads to accumulation of harmful reactive oxygen species (ROS). Plants counteract the toxic effects of heavy metal stress by activating certain metabolic activities and physiological modifications [12]. These protect the plant against free radicals and prevent damage to plant molecules such as lipids, proteins and nucleic acids. Some of the strategies include accumulation of plant secondary metabolites such as antioxidant enzymes, proline, glutathione and phenolic and flavonoids compounds. These plant secondary metabolites play numerous roles in plant protection under different biotic and abiotic influences [13,14]. Phenolic compounds and other secondary metabolites have numerous pharmacological properties and thus any environmental condition that affects either the quantity or composition of phytochemical compounds may potentially influence the efficacy of the medicinal plant product. There is limited information on specific physiological responses of medicinal plants to heavy metals in soils and the resulting changes in the efficacy of the plant $[15,16]$.

Gynura procumbens which belongs to the botanical Compositae family is locally known in Malaysia as 'Sambung nyawa' [17]. This plant is about 15-30 cm high and has succulent, elliptic and glossy purplish leaves. The leaves of G. procumbens have been consumed as a salad for decades in Malaysia. A group of researchers has indicated the presence of multiple classes of compounds in G. procumbens extract such as alkaloids, coumarins, flavonoids, triterpenes, and valepotriates [18]. Due to its content of these secondary metabolites, the plant has been widely used as a traditional medicine to treat cancer, kidney disease, migraines, hypertension and diabetes [17-19]. Extracts of this plant have pharmacological activities such as anti-hyperglycemic, anti-inflammatory and anti-hypertensive effects [19]. Cultivation of this medicinal plant is gaining popularity with increasing government support to meet the high demand for plant materials. Currently, this herb is listed as a high value herbal plant under the Malaysia Agricultural National Key Economic Area Initiative for the herbal 
subsector (NKEA). Normally G. procumbens has been planted in beds for easy cultivation in nurseries. However, a recent study by Ong et al. [20] showed that most surface soils in Malaysia are contaminated with heavy metals, especially $\mathrm{Cd}$ and $\mathrm{Cu}$. This suggested that there might be cadmium and copper contamination in the surface soil used for the preparation of plant beds [21]. There is a concern that these contaminants might be transferred to humans through the food chain [22]. Uptake and accumulation of heavy metals in medicinal plants not only poses a serious safety threat to consumers, but also affects the efficacy and quality of derived medicinal plant products [23,24]. Previously, no study has been conducted to look into the impact of the interactions of cadmium and copper with herbal medicines. This work will provide the basic understanding of heavy metal $(\mathrm{Cd}, \mathrm{Cu})$ relationship with herbal medicine in terms of growth, bioaccumulation, antioxidant and antimicrobial activities. Thus, the aim of the present study was to determine the effects of $\mathrm{Cd}, \mathrm{Cu}$ and its combinations on the growth and heavy metal bioaccumulation in G. procumbens. In addition, total chlorophyll content was quantified as an indication of stress responses to heavy metals. The secondary metabolite content (total phenolics, flavonoids and saponin), antioxidant and antibacterial activity was determined to establish the effect of these heavy metal contamination on the efficacy of G. procumbens.

\section{Results and Discussion}

\subsection{Growth Parameters}

Table 1 shows the growth patterns of G. procumbens under $\mathrm{Cd}$ and $\mathrm{Cu}$ exposure. Generally, it was seen that plant dry weight, total leaf area and basal diameter decrease with increasing $\mathrm{Cd}$ treatments $(p \leq 0.05)$ in G. procumbens. The highest concentration of $\mathrm{Cd}(4 \mathrm{mg} / \mathrm{L})$ decreased the plant dry weight, total leaf area and basal diameter compared to the control plants. Plant dry weight, total leaf area and basal diameter was highest under lowest $\mathrm{Cu}$ treatments $(\mathrm{Cu} 70)$ compared to the highest $\mathrm{Cu}$ treatments (Cu 140). In the current study, growth parameters of G. procumbens grown in the combined treatments $(\mathrm{Cd}+\mathrm{Cu})$ were statistically lower compared to $\mathrm{Cd}$ and $\mathrm{Cu}$ treated plants. The current results indicate that a combination of $\mathrm{Cd}$ and $\mathrm{Cu}$ would reduce growth parameters more compared to the application of $\mathrm{Cd}$ and $\mathrm{Cu}$ alone.

Furthermore, in the correlation Table 2, the growth parameters (plant dry weight, total leaf area and basal diameter) have a significant negative correlation with cadmium and copper. This implies that presence of cadmium and copper would reduce the plant growth. This result was in agreement with work by Di Santo et al. [25] where they observed Quercus pubescence plantlets that were exposed to cadmium and copper had lower growth patterns compared to seedlings treated with cadmium and copper alone. In addition, Deng et al. [26] observed that combination of $\mathrm{Cd}$ and $\mathrm{Cu}$ reduced the growth patterns of germinated maize seeds. Furthermore, Versieran et al. [27] found that $\mathrm{Cu}$ and $\mathrm{Cd}$ combination was more toxic to barley seedlings compared to $\mathrm{Zn}$ and $\mathrm{Cd}$ as measured by inhibition of root elongation in barley seedlings. It can be concluded that growth of this herb on contaminated soils can slow the plant growth by reduction in dry weight accumulation, lower leaf area and reduce thickness of the plant stem. 
Table 1. Plant dry weight, total leaf area, basal diameter, chlorophyll properties of Gynura procumbens to different cadmium and copper treatments.

\begin{tabular}{|c|c|c|c|c|c|c|c|}
\hline Treatments & $\begin{array}{l}\text { Plant Dry Weight } \\
\text { (g) }\end{array}$ & $\begin{array}{l}\text { Total Leaf Area } \\
\left(\mathrm{cm}^{2}\right)\end{array}$ & $\begin{array}{l}\text { Basal Diameter } \\
\text { (mm) }\end{array}$ & $\begin{array}{c}\text { Chlorophyll a } \\
\text { (mg/g Fresh Weight) }\end{array}$ & $\begin{array}{c}\text { Chlorophyll b } \\
\text { (mg/g Fresh Weight) }\end{array}$ & Chlorophyll $a+b$ & Chlorophyll a/b \\
\hline Control & $32.45 \pm 1.23^{a}$ & $425.32 \pm 12.21^{\mathrm{a}}$ & $24.12 \pm 2.34^{\mathrm{a}}$ & $27.52 \pm 1.23^{a}$ & $32.15 \pm 0.23^{a}$ & $59.32 \pm 6.76^{a}$ & $0.84 \pm 0.09^{a}$ \\
\hline $\mathrm{Cd} 2$ & $27.45 \pm 0.34^{b}$ & $397.56 \pm 10.23^{b}$ & $19.32 \pm 0.98^{b}$ & $20.14 \pm 0.54^{b}$ & $28.76 \pm 0.76^{b}$ & $47.12 \pm 3.32^{b}$ & $0.71 \pm 0.02^{b}$ \\
\hline $\mathrm{Cd} 4$ & $23.34 \pm 2.32^{c}$ & $365.21 \pm 8.67^{\mathrm{d}}$ & $17.25 \pm 2.34^{c}$ & $19.21 \pm 2.34^{b}$ & $26.54 \pm 0.21^{c}$ & $45.23 \pm 2.45^{c}$ & $0.73 \pm 0.01^{\mathrm{b}}$ \\
\hline $\mathrm{Cu} 70$ & $24.21 \pm 1.45^{c}$ & $387.21 \pm 9.21^{\mathrm{c}}$ & $18.72 \pm 4.32^{b}$ & $18.23 \pm 2.34^{c}$ & $27.54 \pm 0.34^{c}$ & $45.11 \pm 3.12^{c}$ & $0.67 \pm 0.07^{c}$ \\
\hline $\mathrm{Cu} 140$ & $20.17 \pm 2.45^{\mathrm{d}}$ & $340.17 \pm 6.23 \mathrm{e}^{\mathrm{e}}$ & $15.21 \pm 2.45^{\mathrm{e}}$ & $16.21 \pm 1.32^{\mathrm{d}}$ & $25.43 \pm 1.34^{\mathrm{d}}$ & $41.32 \pm 5.12^{\mathrm{d}}$ & $0.64 \pm 0.03^{c}$ \\
\hline $\mathrm{Cd} 2+\mathrm{Cu} 70$ & $17.56 \pm 1.21^{\mathrm{e}}$ & $320.12 \pm 7.34^{\mathrm{f}}$ & $17.21 \pm 1.43^{c}$ & $13.21 \pm 2.31^{\mathrm{e}}$ & $24.56 \pm 1.45^{\mathrm{e}}$ & $37.21 \pm 0.23^{\mathrm{e}}$ & $0.54 \pm 0.02^{\mathrm{d}}$ \\
\hline $\mathrm{Cd} 2+\mathrm{Cu} 140$ & $15.32 \pm 0.21^{\mathrm{f}}$ & $301.23 \pm 5.64^{g}$ & $16.32 \pm 3.23^{d}$ & $11.23 \pm 1.21^{\mathrm{f}}$ & $23.21 \pm 2.34^{f}$ & $34.21 \pm 0.78^{f}$ & $0.47 \pm 0.04^{\mathrm{e}}$ \\
\hline $\mathrm{Cd} 4+\mathrm{Cu} 70$ & $12.31 \pm 1.23 \mathrm{~g}$ & $311.24 \pm 2.45^{\mathrm{h}}$ & $13.21 \pm 3.12^{\mathrm{f}}$ & $11.67 \pm 2.14^{\mathrm{f}}$ & $23.44 \pm 4.22^{\mathrm{f}}$ & $33.23 \pm 0.98^{f}$ & $0.48 \pm 0.07^{\mathrm{e}}$ \\
\hline $\mathrm{Cd} 4+\mathrm{Cu} 140$ & $12.52 \pm 1.23 \mathrm{~g}$ & $290.32 \pm 3.45^{\mathrm{i}}$ & $12.12 \pm 0.23 \mathrm{~g}$ & $10.21 \pm 4.21 \mathrm{~g}$ & $21.23 \pm 2.45 \mathrm{~g}$ & $30.34 \pm 1.23 \mathrm{~g}$ & $0.47 \pm 0.05^{\mathrm{e}}$ \\
\hline
\end{tabular}

All analyses are mean \pm standard error of mean (SEM), $\mathrm{N}=15$. Means not sharing a common single letter were significantly different at $p \leq 0.05$ using Duncan Multiple Range Test (DNMRT). Cd 2 = cadmium $2 \mathrm{mg} / \mathrm{L} ; \mathrm{Cd} 4=$ cadmium $4 \mathrm{mg} / \mathrm{L} ; \mathrm{Cu} 70=$ copper $70 \mathrm{mg} / \mathrm{L} ; \mathrm{Cu} 140=$ copper $140 \mathrm{mg} / \mathrm{L} ; \mathrm{Cd} 2+\mathrm{Cu} 70=\mathrm{cadmium} 2 \mathrm{mg} / \mathrm{L}+\mathrm{copper} 70 \mathrm{mg} / \mathrm{L} ; \mathrm{Cd} 2+\mathrm{Cu} 140=$ cadmium $2 \mathrm{mg} / \mathrm{L}+$ copper $140 \mathrm{mg} / \mathrm{L} ; \mathrm{Cd} 4+\mathrm{Cu} 70=$ cadmium $4 \mathrm{mg} / \mathrm{L}+$ copper $70 \mathrm{mg} / \mathrm{L} ; \mathrm{Cd} 4+\mathrm{Cu} 140=$ cadmium $4 \mathrm{mg} / \mathrm{L}+$ copper $140 \mathrm{mg} / \mathrm{L}$.

Table 2. Correlations among the measured parameters in the experiments.

\begin{tabular}{|c|c|c|c|c|c|c|c|c|c|c|c|c|c|}
\hline Parameters & 1 & 2 & 3 & 4 & 5 & 6 & 7 & 8 & 9 & 10 & 11 & 12 & 13 \\
\hline 1. T. Biomass & 1.000 & & & & & & & & & & & & \\
\hline 2. Area & 0.321 & 1.000 & & & & & & & & & & & \\
\hline 3. Basal & 0.223 & 0.213 & 1.000 & & & & & & & & & & \\
\hline 4. T.Chlorophyll & 0.432 & 0.432 & 0.211 & 1.000 & & & & & & & & & \\
\hline 5. Cadmium & -0.671 * & -0.321 & -0.567 * & $-0.765 *$ & 1.000 & & & & & & & & \\
\hline 6. Copper & -0.621 * & -0.561 * & -0.444 & 0.432 & $0.671 *$ & 1.000 & & & & & & & \\
\hline 7. T.phenolics & 0.213 & 0.213 & 0.231 & -0.871 * & $0.761 *$ & $0.661 *$ & 1.000 & & & & & & \\
\hline 8. T flavonoids & 0.098 & 0.123 & 0.116 & $-0.712 *$ & 0.665 & $0.687^{*}$ & $0.876^{*}$ & 1.000 & & & & & \\
\hline 9. Saponins & 0.321 & 0.091 & 0.092 & $-0.812 *$ & 0.521 & $0.622 *$ & $0.812 *$ & $0.776^{*}$ & 1.000 & & & & \\
\hline 10. PAL activity & 0.021 & 0.034 & 0.112 & $0.321 *$ & $0.776 *$ & 0.556 & $0.763 *$ & $0.886 *$ & $0.811 *$ & 1.000 & & & \\
\hline 11. DPPH & 0.231 & 0.091 & 0.121 & 0.221 & 0.776 * & 0.453 & $0.879 *$ & $0.910 *$ & $0.762 *$ & $0.891 *$ & 1.000 & & \\
\hline 12. FRAP & 0.121 & 0.213 & 0.005 & 0.234 & 0.662 & 0.321 & $0.912 *$ & $0.927 *$ & $0.874 *$ & $0.932 *$ & $0.782 *$ & 1.000 & \\
\hline 13. Antibacterial & 0.123 & 0.217 & 0.321 & 0.453 & 0.091 & 0.231 & $0.901 *$ & $0.892 *$ & $0.921 *$ & $0.875 *$ & $0.862 *$ & $0.877 *$ & 1.000 \\
\hline
\end{tabular}

* Significant at $p \leq 0.05$. 


\subsection{Total Chlorophyll Content}

The impact of $\mathrm{Cd}$ and $\mathrm{Cu}$ on total chlorophyll content of G. procumbens is presented in Table 1. The total chlorophyll content decreased with increasing rates of $\mathrm{Cd}$ and $\mathrm{Cu}$. This herb has higher levels of chlorophyll $b$ than chlorophyll a. The result suggested that the decrease in total chlorophyll content in this plant likely to be due to degradation of chlorophyll synthesis under exposure to high levels of $\mathrm{Cd}$ and $\mathrm{Cu}$. Chlorophyll content is often measured in plants in order to assess the impact of environmental stress, as changes in pigment content are linked to visual symptoms of plant illness and photosynthetic productivity [28]. Heavy metals inhibit metabolic processes by inhibiting the action of enzymes, and this may be the most important cause of chlorophyll degradation. Decreased chlorophyll content associated with heavy metal stress may be the result of inhibition of the enzymes responsible for chlorophyll biosynthesis [29]. In the present study, total chlorophyll content was found to be negatively correlated with cadmium $\left(\mathrm{r}^{2}=-0.765 ; p \leq 0.05\right.$; Table 2$)$. This suggests that cadmium might play the role in reduction of total chlorophyll content in the present study. This was supported by study by Tuna et al. [30] on maize that found among heavy metals such as lead, copper and mercury, cadmium had a more profound effect in reducing the TCC compared to the influence of other heavy metals. It can be concluded from the present study that exposure to heavy metals can reduce TCC content by reduction in chlorophyll $\mathrm{a}$ and $\mathrm{b}$ as observed in G. procumbens.

\subsection{Uptake and Distribution of $\mathrm{Cd}$ and $\mathrm{Cu}$ in Plants}

Root to shoot translocation of the two heavy metals in G. procumbens is shown in Table 3. The Cd concentration was lower in the shoot compared to the root. Similarly, the translocation of $\mathrm{Cu}$ also was poor $(\mathrm{TF}<1)$. The highest level of $\mathrm{Cu}$ was observed in the roots compared to the shoots. The highest $\mathrm{TF}$ for $\mathrm{Cd}$ and $\mathrm{Cu}$ was observed in the combined treatment of $\mathrm{Cd} 2+\mathrm{Cu} 70$. Accumulation of $\mathrm{Cd}$ and $\mathrm{Cu}$ was lower in the shoots compared to the roots, which indicated a slow translocation of these elements from the root to the shoot part. From the result, it also can be concluded that this plant was not a hyperaccumulator. Usually, a plant that accumulates high concentrations of Cd and Cu (>100 mg/kg and $1000 \mathrm{mg} / \mathrm{kg}$ respectively) in their tissue can be categorized as a hyperaccumulator [31]. Although this plant is not a hyperaccumulator, when exposed to the heavy metals in the present study, this plant could accumulate $\mathrm{Cd}$ and $\mathrm{Cu}$ above the WHO-recommended safety limits that are $0.3 \mathrm{mg} / \mathrm{kg}$ and $1.3 \mathrm{mg} / \mathrm{kg}$, respectively [32]. At low doses, cadmium can directly induce toxic effects that affect mainly the human kidney and liver. Chronic exposure of the human body can induce a disease called itai-itai, in which patients show a wide range of symptoms such as low grades of bone mineralization, high rates of fractures, increased rates of osteoporosis, and intense bone-associated pain [30]. Ingestion of high levels of copper can cause copper poisoning that is indicated by vomiting of blood, low blood pressure, melena, jaundice and gastrointestinal distress [33]. This result shows that there should be a concern for human safety when this plant is used for medicinal purposes. Correlation Table 2 shows that cadmium and copper were positively correlated $\left(\mathrm{r}^{2}=0.671 ; p \leq 0.05\right)$ which indicates these heavy metals are not antagonistic to each other. Addition of cadmium and copper has been shown to severely reduce plant growth as shows by a reduction of total plant biomass, leaf area and basal diameter. 
Table 3. Uptake and translocation factor (TF) of $\mathrm{Cd}$ and $\mathrm{Cu}$ in Gynura procumbens roots and shoot under different cadmium and copper treatments. $\mathrm{ND}=$ not detected.

\begin{tabular}{|c|c|c|c|c|c|c|}
\hline \multirow{2}{*}{ Treatments } & \multicolumn{3}{|c|}{ Cd Concentration (mg/kg) } & \multicolumn{3}{|c|}{ Cu Concentration $(\mathrm{mg} / \mathrm{kg})$} \\
\hline & Root & Shoot & TF & Root & Shoot & TF \\
\hline Control & ND & ND & ND & ND & ND & ND \\
\hline $\mathrm{Cd} 2$ & $1.21 \pm 0.21^{\mathrm{e}}$ & $0.76 \pm 0.09^{d}$ & 0.62 & ND & ND & ND \\
\hline $\mathrm{Cd} 4$ & $2.31 \pm 0.16^{b}$ & $1.21 \pm 0.01^{\mathrm{b}}$ & 0.52 & ND & ND & ND \\
\hline $\mathrm{Cu} 70$ & ND & ND & ND & $35.61 \pm 1.23^{c}$ & $24.43 \pm 0.12^{\mathrm{d}}$ & 0.68 \\
\hline $\mathrm{Cu} 140$ & ND & ND & ND & $66.43 \pm 0.76^{b}$ & $37.45 \pm 1.34^{b}$ & 0.56 \\
\hline $\mathrm{Cd} 2+\mathrm{Cu} 70$ & $1.17 \pm 0.21^{\mathrm{e}}$ & $1.32 \pm 0.21^{\mathrm{a}}$ & 1.12 & $34.56 \pm 1.45^{\mathrm{d}}$ & $32.12 \pm 0.76^{c}$ & 0.94 \\
\hline $\mathrm{Cd} 2+\mathrm{Cu} 140$ & $1.45 \pm 0.09^{\mathrm{d}}$ & $1.43 \pm 0.17^{\mathrm{a}}$ & 0.98 & $75.23 \pm 2.34^{\mathrm{a}}$ & $54.16 \pm 1.23^{\mathrm{a}}$ & 0.71 \\
\hline $\mathrm{Cd} 4+\mathrm{Cu} 70$ & $2.65 \pm 0.21^{a}$ & $1.26 \pm 0.11^{\mathrm{b}}$ & 0.47 & $38.32 \pm 1.63^{c}$ & $32.12 \pm 0.34^{c}$ & 0.83 \\
\hline $\mathrm{Cd} 4+\mathrm{Cu} 140$ & $2.15 \pm 0.42^{c}$ & $0.98 \pm 0.12^{\mathrm{c}}$ & $0 . .45$ & $72.31 \pm 1.21^{\mathrm{a}}$ & $52.34 \pm 1.45^{\mathrm{a}}$ & 0.72 \\
\hline
\end{tabular}

All analyses are mean \pm standard error of mean (SEM), $\mathrm{N}=15$. Means not sharing a common single letter were significantly different at $p \leq 0.05$ using Duncan Multiple Range Test (DNMRT). Cd $2=$ cadmium $2 \mathrm{mg} / \mathrm{L}$; $\mathrm{Cd} 4=$ cadmium $4 \mathrm{mg} / \mathrm{L} ; \mathrm{Cu} 70=$ copper $70 \mathrm{mg} / \mathrm{L} ; \mathrm{Cu} 140=$ copper $140 \mathrm{mg} / \mathrm{L} ; \mathrm{Cd} 2+\mathrm{Cu} 70=$ cadmium $2 \mathrm{mg} / \mathrm{L}+$ copper $70 \mathrm{mg} / \mathrm{L} ; \mathrm{Cd} 2+\mathrm{Cu} 140=$ cadmium $2 \mathrm{mg} / \mathrm{L}+$ copper $140 \mathrm{mg} / \mathrm{L} ; \mathrm{Cd} 4+\mathrm{Cu} 70$ = cadmium $4 \mathrm{mg} / \mathrm{L}+$ copper $70 \mathrm{mg} / \mathrm{L} ; \mathrm{Cd} 4+\mathrm{Cu} 140=$ cadmium $4 \mathrm{mg} / \mathrm{L}+$ copper $140 \mathrm{mg} / \mathrm{L}$.

\subsection{Total Phenolics and Flavonoids}

Accumulation of total phenolics and flavonoids in G. procumbens was influenced by the treatments $(p \leq 0.01$; Table 4). Generally, total phenolics and flavonoids was observed to be the highest for Cd 2 (4.21 mg gallic acid/g dry weight) and the lowest for Cd $4+\mathrm{Cu} 140$ (1.24 mg gallic acid/g dry weight). Total flavonoids content followed the same trend as total phenolics, where the highest total flavonoids content was observed for $\mathrm{Cd} 2$ which registered $3.21 \mathrm{mg}$ rutin/g dry. The lowest weight was recorded for $\mathrm{Cd} 4+\mathrm{Cu} 140$ which contained only $0.65 \mathrm{mg}$ rutin/g dry weight. The present results are in agreement with the findings of Lakhdar et al. [34] who found tha municipal waste rich in cadmium and copper enhanced the production of total phenolics and flavonoids by $10 \%$ and $7 \%$ respectively in Mesembryanthemum edule. In a previous study conducted by Okem et al. [35] on Hypoxis hemerocallidera exposed to cadmium and aluminium they observed the same pattern as our result whereby production of total phenolics and flavonoids was highly reduced when the plant was exposed to a combination of heavy metals. They also found that exposure to lower levels of single heavy metals enhances the production of secondary metabolites. In the present study, the highest production of total phenolics and flavonoids was observed for $\mathrm{Cd} 2$ and $\mathrm{Cu} 70$ i.e., the lowest level of $\mathrm{Cd}$ and $\mathrm{Cu}$ exposure. The present result suggests that in the current environment where there is a lot of heavy metal contaminants in the soil, the production of secondary metabolites might be reduced due to interactions between these heavy metals. The results imply that G. procumbens planted on soil contaminated with heavy metals might show reduced production of secondary metabolites in the plant. Although, the total phenolics and flavonoids was enhanced with increased $\mathrm{Cd}$ or $\mathrm{Cu}$ application the cultivated G. procumbens plants are not safe to be consumed due to the high bioaccumulation of heavy metals that is above the safety levels recommended by the WHO. 
Table 4. Total phenolics, total flavonoids and total saponin content of Gyanura procumbens under different cadmium and copper treatments.

\begin{tabular}{|c|c|c|c|}
\hline $\begin{array}{l}\text { Treatments } \\
(\mathrm{mg} / \mathrm{L})\end{array}$ & $\begin{array}{l}\text { Total Phenolics } \\
\text { (mg/g DM GAE ) }\end{array}$ & $\begin{array}{l}\text { Total Flavonoids } \\
\text { (mg/g DM Rutin) }\end{array}$ & $\begin{array}{c}\text { Total Saponin } \\
\text { (mg/g DM Diosgenin) }\end{array}$ \\
\hline Control & $2.15 \pm 0.15^{\mathrm{e}}$ & $1.25 \pm 0.13^{\mathrm{e}}$ & $28.61 \pm 1.23 \mathrm{~g}$ \\
\hline $\mathrm{Cd} 2$ & $4.21 \pm 0.21^{\mathrm{a}}$ & $3.21 \pm 0.14^{\mathrm{a}}$ & $56.71 \pm 2.34^{\mathrm{a}}$ \\
\hline $\mathrm{Cd} 4$ & $3.21 \pm 0.14^{\mathrm{c}}$ & $2.76 \pm 0.67^{b}$ & $45.62 \pm 1.13^{c}$ \\
\hline $\mathrm{Cu} 70$ & $4.02 \pm 0.21^{\mathrm{a}}$ & $2.87 \pm 0.45^{b}$ & $50.21 \pm 2.45^{b}$ \\
\hline $\mathrm{Cu} 140$ & $3.76 \pm 0.54^{b}$ & $2.45 \pm 0.27^{c}$ & $40.21 \pm 2.12^{\mathrm{d}}$ \\
\hline $\mathrm{Cd} 2+\mathrm{Cu} 70$ & $2.56 \pm 0.21^{d}$ & $2.21 \pm 0.13^{c}$ & $32.13 \pm 3.21^{\mathrm{e}}$ \\
\hline $\mathrm{Cd} 2+\mathrm{Cu} 140$ & $1.78 \pm 0.32^{f}$ & $1.76 \pm 0.09^{d}$ & $24.34 \pm 1.76^{f}$ \\
\hline $\mathrm{Cd} 4+\mathrm{Cu} 70$ & $1.65 \pm 0.15^{f}$ & $0.98 \pm 0.13^{f}$ & $20.45 \pm 1.21^{h}$ \\
\hline $\mathrm{Cd} 4+\mathrm{Cu} 140$ & $1.24 \pm 0.14^{g}$ & $0.65 \pm 0.17^{g}$ & $18.75 \pm 1.76^{\mathrm{i}}$ \\
\hline
\end{tabular}

All analyses are mean \pm standard error of mean (SEM), $N=15$. Means not sharing a common single letter were significantly different at $p \leq 0.05$ using Duncan Multiple Range Test (DNMRT). Cd $2=$ cadmium $2 \mathrm{mg} / \mathrm{L}$; $\mathrm{Cd} 4$ = cadmium $4 \mathrm{mg} / \mathrm{L} ; \mathrm{Cu} 70=$ copper $70 \mathrm{mg} / \mathrm{L} ; \mathrm{Cu} 140=$ copper $140 \mathrm{mg} / \mathrm{L} ; \mathrm{Cd} 2+\mathrm{Cu} 70=$ cadmium $2 \mathrm{mg} / \mathrm{L}+$ copper $70 \mathrm{mg} / \mathrm{L} ; \mathrm{Cd} 2+\mathrm{Cu} 140=$ cadmium $2 \mathrm{mg} / \mathrm{L}+$ copper $140 \mathrm{mg} / \mathrm{L} ; \mathrm{Cd} 4+\mathrm{Cu} 70=$ cadmium $4 \mathrm{mg} / \mathrm{L}+$ copper $70 \mathrm{mg} / \mathrm{L} ; \mathrm{Cd} 4+\mathrm{Cu} 140=$ cadmium $4 \mathrm{mg} / \mathrm{L}+$ copper $140 \mathrm{mg} / \mathrm{L}$.

\subsection{Saponin Content}

In Table 4 the application of cadmium and copper give significant differences $(p<0.05)$ in the leaf saponin contents in G. procumbens. At the end of the experiment, $\mathrm{Cd} 4+\mathrm{Cu} 140$ treatment produced the lowest saponin content (18.75 mg diosgenin equivalent/g DM) compared to $20.45 \mathrm{mg}$ diosgenin equivalent/g DM by Cd $4+\mathrm{Cu} 70,24.34 \mathrm{mg}$ diosgenin equivalent/g DM by Cd $2+\mathrm{Cu} 140$, $28.61 \mathrm{mg}$ diosgenin equivalent/g DM by control, $32.13 \mathrm{mg}$ diosgenin equivalent/g DM by Cd $2+$ $\mathrm{Cu} 70,40.21 \mathrm{mg}$ diosgenin equivalent/g DM by Cu 140, $45.62 \mathrm{mg}$ diosgenin equivalent/g DM by Cd 4, $50.21 \mathrm{mg}$ diosgenin equivalent/g DM by Cu 70 and $56.71 \mathrm{mg}$ diosgenin equivalent/g DM by Cd 2 treatment. This showed that the total saponin content in the $\mathrm{Cd} 2, \mathrm{Cd} 4, \mathrm{Cu} 70$ groups was enhanced and it decreased in the $\mathrm{Cu} 140, \mathrm{Cd} 2+\mathrm{Cu} 70, \mathrm{Cd} 2+140, \mathrm{Cd} 4+\mathrm{Cu} 70$ and $\mathrm{Cd} 4+\mathrm{Cu} 140$ treatments compared to the control plants. Saponins occur naturally in soybeans, peas, ginseng, herbs, vegetables and yucca [36]. They are phytochemicals, or plant chemicals, possessing detergent qualities that foam when mixed with water. Commercially, saponins are used in beverages and cosmetics as emulsifiers or sweeteners and also fed to livestock to cut down on odour because they bind to ammonia, which contributes to foul smells [37]. It's believed saponins have a favorable effect on cholesterol levels, can help boost the immune system, have an antioxidant effect, and may even support bone strength [38]. In the current results it was shown that production of diosgenin was reduced when exposed to combination cadmium and copper treatments. Diosgenin is a very important plant phytochemical that possesses medicinal properties, including hypo-cholesterolemic, anti-carcinogenic, anti-inflammatory, antimicrobial and antioxidant activities. This showed the reduction of saponins under combined heavy metal treatments would reduce the medicinal properties of this plant [39].

\subsection{Antibacterial Activity}

The antibacterial activity of G. procumbens leaves was tested using the disc diffusion methods at a concentration of $300 \mu \mathrm{g} /$ disc. The results, show, in Table 5, indicate a significant $(p<0.05)$ inhibitory activity between all of the treatments. The extract showed moderate to appreciable antimicrobial activities against two Gram positive and two Gram negative bacteria. It was found that after single treatment the plant had higher antimicrobial activities compared to the combination treatments in both Gram positive and Gram negative bacteria. The highest antibacterial activity was observed for $\mathrm{Cd} 2$ and $\mathrm{Cu} 70$ treatment and lowest under combination $\mathrm{Cd}$ and $\mathrm{Cu}$ treatments like $\mathrm{Cd} 4+\mathrm{Cu} 70$ and $\mathrm{Cd} 4$ $+\mathrm{Cu} 140$. In the present study, the highest inhibition zones that ranged from 8.23-9.67 mm in Gram positive and 9.14-9.34 in Gram negative bacteria were obtained after $\mathrm{Cd} 2$ treatments. Nyastatin as 
standard antimicrobial showed a high inhibition zone at a concentration of $1 \mu \mathrm{g} / \mathrm{disc}$. The decreased antimicrobial activities under combined treatments of $\mathrm{Cd}$ and $\mathrm{Cu}$ can be attributed to a decrease in the production of plant secondary metabolites under these conditions. In a recent study, the production of total phenolics, flavonoids and saponin was lowest under combined treatments. Furthermore, total phenolics $\left(\mathrm{r}^{2}=0.901 ; p \leq 0.05\right.$; Table 3$)$, flavonoids $\left(\mathrm{r}^{2}=0.892 ; p \leq 0.05\right.$; Table 3$)$ and saponin content $\left(\mathrm{r}^{2}=0.921 ; p \leq 0.05\right.$; Table 3$)$ had a significant positive correlation with antibacterial activity in the present study. This indicates that the antibacterial activity was influenced by the total phenolics, total flavonoids and saponin content in the plant. A higher secondary metabolites content would enhance the antibacterial activity in G. procumbens plant. The same result was also obtained by Okem et al. [35] on Drimia elata, where they found the highest antibacterial activity (minimum inhibition concentration; MIC) was observed under single heavy metal treatment (cadmium and aluminium) compared to the combination of $\mathrm{Cd}$ and Al. Their other study on Hypoxis hemerocallidera [40] also obtained the same result where the combination treatment of $\mathrm{Cd}$ and $\mathrm{Al}$ produced the lowest secondary metabolites content and this reduced the antimicrobial activity of the plant. It is apparent that in Table 5, Gram positive bacteria have higher sensitivity than Gram negative ones. The reason that Gram-positive bacteria have a higher antibacterial-sensitivity than Gram-negative bacteria could be the differences in their cell membrane constituents [41]. The outer membrane of the Gram-negative cell wall comprises structural lipopolysaccharides, which render the cell wall impermeable to lipophilic solutes, unlike Gram-positive bacteria, which lack this outer membrane [42]. This morphological difference influences their sensitivity to antibacterial agents. The antibacterial activity also was found to be positively correlated with the plant secondary metabolites, so it can be concluded that in the present study a lower production of secondary metabolites under the combination treatment of cadmium and copper would reduce the secondary metabolites content and reduce the antimicrobial activity of G. procumbens.

Table 5. Antimicrobial activity of Gynura procumbens leaves crude extracts of different cadmium and copper treatments based on disc diffusion method.

\begin{tabular}{ccccc}
\hline \multirow{2}{*}{ Treatments } & \multicolumn{4}{c}{ Inhibition Zone (mm) } \\
\cline { 2 - 5 } & \multicolumn{2}{c}{ Gram Positive Bacteria } & \multicolumn{2}{c}{ Gram Negative Bacteria } \\
\cline { 2 - 5 } & B. subtilis & S. aureus & E. coli & K. pneumonie \\
\hline Control & $7.65 \pm 0.11^{\mathrm{d}}$ & $6.32 \pm 0.11^{\mathrm{f}}$ & $7.26 \pm 0.12^{\mathrm{d}}$ & $8.88 \pm 0.21^{\mathrm{c}}$ \\
Cd 2 & $9.67 \pm 0.14^{\mathrm{b}}$ & $8.23 \pm 0.21^{\mathrm{b}}$ & $9.34 \pm 0.09^{\mathrm{b}}$ & $9.25 \pm 0.23^{\mathrm{b}}$ \\
Cd 4 & $8.21 \pm 0.21^{\mathrm{c}}$ & $7.32 \pm 0.14^{\mathrm{c}}$ & $8.78 \pm 0.23^{\mathrm{c}}$ & $8.23 \pm 0.15^{\mathrm{d}}$ \\
Cu 70 & $9.11 \pm 0.09^{\mathrm{b}}$ & $8.12 \pm 0.12^{\mathrm{b}}$ & $9.12 \pm 0.45^{\mathrm{b}}$ & $9.06 \pm 0.12^{\mathrm{b}}$ \\
Cu 140 & $8.03 \pm 0.23^{\mathrm{c}}$ & $7.21 \pm 0.21^{\mathrm{c}}$ & $8.26 \pm 0.12^{\mathrm{c}}$ & $8.17 \pm 0.12^{\mathrm{d}}$ \\
Cd 2 + Cu 70 & $7.34 \pm 0.11^{\mathrm{d}}$ & $7.02 \pm 0.12^{\mathrm{d}}$ & $7.23 \pm 0.45^{\mathrm{d}}$ & $7.45 \pm 0.11^{\mathrm{e}}$ \\
Cd 2 + Cu 140 & $7.21 \pm 0.21^{\mathrm{e}}$ & $6.98 \pm 0.21^{\mathrm{e}}$ & $7.02 \pm 0.67^{\mathrm{e}}$ & $7.56 \pm 0.13^{\mathrm{e}}$ \\
Cd 4 Cu 70 & $6.12 \pm 0.23^{\mathrm{f}}$ & $6.56 \pm 0.14^{\mathrm{f}}$ & $6.78 \pm 0.21^{\mathrm{f}}$ & $6.42 \pm 0.13^{\mathrm{f}}$ \\
Cd 4 + Cu 140 & $6.56 \pm 0.12^{\mathrm{f}}$ & $6.09 \pm 0.21^{\mathrm{g}}$ & $6.56 \pm 0.16^{\mathrm{f}}$ & $6.01 \pm 0.23^{\mathrm{f}}$ \\
Nyastatin * & $12.12 \pm 0.14^{\mathrm{a}}$ & $11.21 \pm 0.37^{\mathrm{a}}$ & $13.54 \pm 0.31^{\mathrm{a}}$ & $11.45 \pm 0.16^{\mathrm{a}}$ \\
\hline
\end{tabular}

* At $100 \mu \mathrm{g} / \mathrm{mL}$. All analyses are mean \pm standard error of mean (SEM), $\mathrm{N}=15$. Means not sharing a common single letter were significantly different at $p \leq 0.05$ using Duncan Multiple Range Test (DNMRT). Cd $2=$ cadmium $2 \mathrm{mg} / \mathrm{L} ; \mathrm{Cd} 4$ = cadmium $4 \mathrm{mg} / \mathrm{L} ; \mathrm{Cu} 70=$ copper $70 \mathrm{mg} / \mathrm{L} ; \mathrm{Cu} 140=$ copper $140 \mathrm{mg} / \mathrm{L} ; \mathrm{Cd} 2+\mathrm{Cu} 70=$ cadmium $2 \mathrm{mg} / \mathrm{L}+$ copper $70 \mathrm{mg} / \mathrm{L} ; \mathrm{Cd} 2+\mathrm{Cu} 140=$ cadmium $2 \mathrm{mg} / \mathrm{L}+$ copper $140 \mathrm{mg} / \mathrm{L} ; \mathrm{Cd} 4+\mathrm{Cu} 70=$ cadmium $4 \mathrm{mg} / \mathrm{L}$ + copper $70 \mathrm{mg} / \mathrm{L} ; \mathrm{Cd} 4+\mathrm{Cu} 140=$ cadmium $4 \mathrm{mg} / \mathrm{L}+$ copper $140 \mathrm{mg} / \mathrm{L}$.

\subsection{Phenylalanine Ammonia Lyase (PAL) Activity}

Figure 1 shows the phenylalanine ammonia lyase (PAL) activity was affected $(p \leq 0.05)$ by the heavy metal treatments. In general, it was observed that the mixture of cadmium and copper reduced the activity of this enzyme in G. procumbens. The highest PAL activity was found to be under Cd 2 treatment that recorded $2.56 \mathrm{nM}$ trans-cinnamic acid $\mathrm{mg} /$ protein/h and the lowest was at control, which only registered $0.87 \mathrm{nM}$ trans-cinnamic acid $\mathrm{mg} /$ protein/h. The increase of PAL activity with 
increasing rate $\mathrm{Cd}$ and $\mathrm{Cu}$ might be due to restrictions in protein production due to a limited nitrogen pool under these heavy metal exposure conditions. In the current study, this was shown by reduced total chlorophyll content under these condition that make more phenylalanine available for secondary metabolites production [43]. Correlation analysis revealed that PAL activity had a significant positive correlation with total phenolics $\left(\mathrm{r}^{2}=0.763 ; p \leq 0.05\right)$ total flavonoids $\left(\mathrm{r}^{2}=0.886 ; p \leq 0.05\right)$ and saponin content $\left(\mathrm{r}^{2}=0.811 ; p \leq 0.05\right)$, suggesting when plants are exposed to $\mathrm{Cd}$ and $\mathrm{Cu}$, PAL activity would be enhanced and subsequently increase the production of plant secondary metabolites. This was supported by a high and positive correlation coefficient between $\mathrm{Cd}\left(\mathrm{r}^{2}=0.776\right)$ and $\mathrm{Cu}\left(\mathrm{r}^{2}=0.556\right)$ with PAL activity that was observed in the present study. The present result was an agreement with the study of Kovacik et al. [44] in Matricaria chamomilla, where they observed the stimulation of PAL activity when chamomile was consecutively exposed to excess cadmium (Cd) and copper $(\mathrm{Cu})(3,60$, and $120 \mu \mathrm{M}$ ) for seven days.

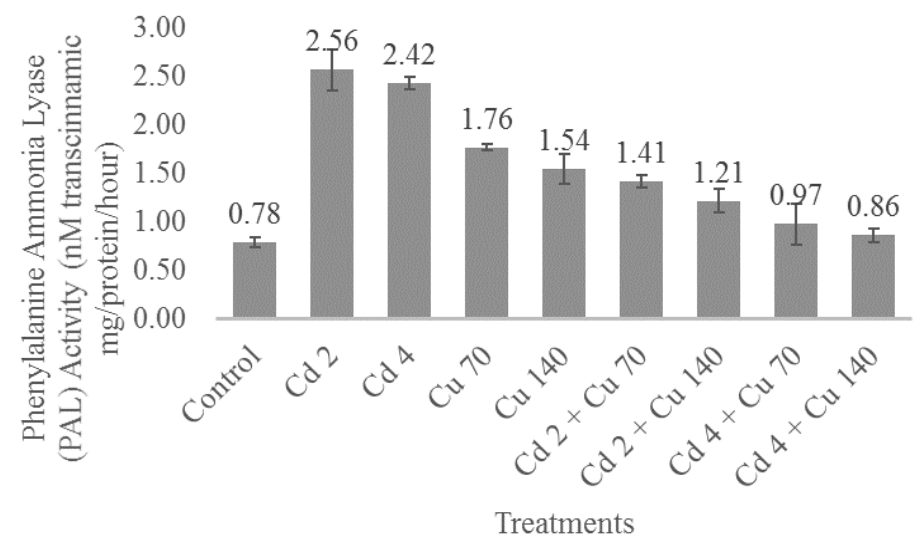

Figure 1. The impact of cadmium and copper on PAL activity of G. procumbens. Bars represents standard error of differences between the means. $\mathrm{N}=15 . \mathrm{Cd} 2=$ cadmium $2 \mathrm{mg} / \mathrm{L} ; \mathrm{Cd} 4=$ cadmium $4 \mathrm{mg} / \mathrm{L} ; \mathrm{Cu} 70=$ copper $70 \mathrm{mg} / \mathrm{L} ; \mathrm{Cu} 140=$ copper $140 \mathrm{mg} / \mathrm{L} ; \mathrm{Cd} 2+\mathrm{Cu} 70=$ cadmium $2 \mathrm{mg} / \mathrm{L}+$ Copper $70 \mathrm{mg} / \mathrm{L} ; \mathrm{Cd} 2+\mathrm{Cu} 140=$ cadmium $2 \mathrm{mg} / \mathrm{L}+$ copper $140 \mathrm{mg} / \mathrm{L} ; \mathrm{Cd} 4+\mathrm{Cu} 70=$ cadmium $4 \mathrm{mg} / \mathrm{L}+$ copper $70 \mathrm{mg} / \mathrm{L} ; \mathrm{Cd} 4+\mathrm{Cu} 140=$ cadmium $4 \mathrm{mg} / \mathrm{L}+\operatorname{copper} 140 \mathrm{mg} / \mathrm{L}$.

\subsection{DPPH Radical Scavenging Assay and Reducing Ability (FRAP Assay)}

Figures 2 and 3 show the DPPH and FRAP activity of the leaf extracts of G. procumbens under different cadmium and copper treatments. Generally, DPPF and FRAP activity was influenced by the heavy metal treatments $(p \leq 0.05)$. DPPH radical scavenging activity was used to gauge the antioxidant activity of the G. procumbens leaf extracts to the heavy metal treatments. DPPH antioxidant activity in the two-heavy metal exposure ranged from $29.2 \%$ to $57.5 \%$. Cd 2 treatments showed the highest DPPH activity compared to $\mathrm{Cu} 70$ treatments. With a two-fold increase in $\mathrm{Cd}$ and $\mathrm{Cu}$ levels the DPPH activity of the plant extracts decreased significantly. The lowest DPPH was observed in Cd $4+$ $\mathrm{Cu} 140$ where it just recorded only $29.3 \%$. The treatment extracts showed the lowest DPPH activity compared to positive controls (BHT: $75.4 \%$ and $\alpha$ tocopherol: $88.4 \%$ ). The FRAP value of G. procumbens leaves extracts ranged from 398.41-680.32 $\mu \mathrm{M}$ of Fe(II)/g. The highest FRAP activity was observed in $\mathrm{Cu} 70$. Results of the FRAP assay showed that as the rate of cadmium and copper doubled the FRAP activity of leaves extract was reduced significantly. The largest decrease was observed under $\mathrm{Cd} 4+$ $\mathrm{Cu} 140$ treatment that only recorded $398.4 \mu \mathrm{M}$ of Fe(II). The decrease in antioxidant potential in the leaves under combined heavy metal treatment could be related to the reduction in the content of some phytochemicals, such as total phenolics, total flavonoids and saponin under these conditions. In the present study, there was a positive correlation between total phenolics, flavonoids and saponin content with DPPH and FRAP activity. Positive correlations between level of secondary metabolites and anti-oxidant properties were demonstrated by previous studies [45-49]. Our finding is consistent with 
previous studies indicating that the levels of secondary metabolites (phenolics and flavonoids, saponin) correspond to the free radical scavenging potential of the medicinal plants [50-53]. The present study suggests that the antioxidant activity of G. procumbens would reduce under combination of cadmium and copper. Although, the antioxidant and antibacterial activities was high under single treatments compared to the combined treatments of $\mathrm{Cd}$ and $\mathrm{Cu}$, the plant extractx are not safe to be consumed due to higher $\mathrm{Cd}$ and $\mathrm{Cu}$ levels than recommended by the WHO observed in the present study.

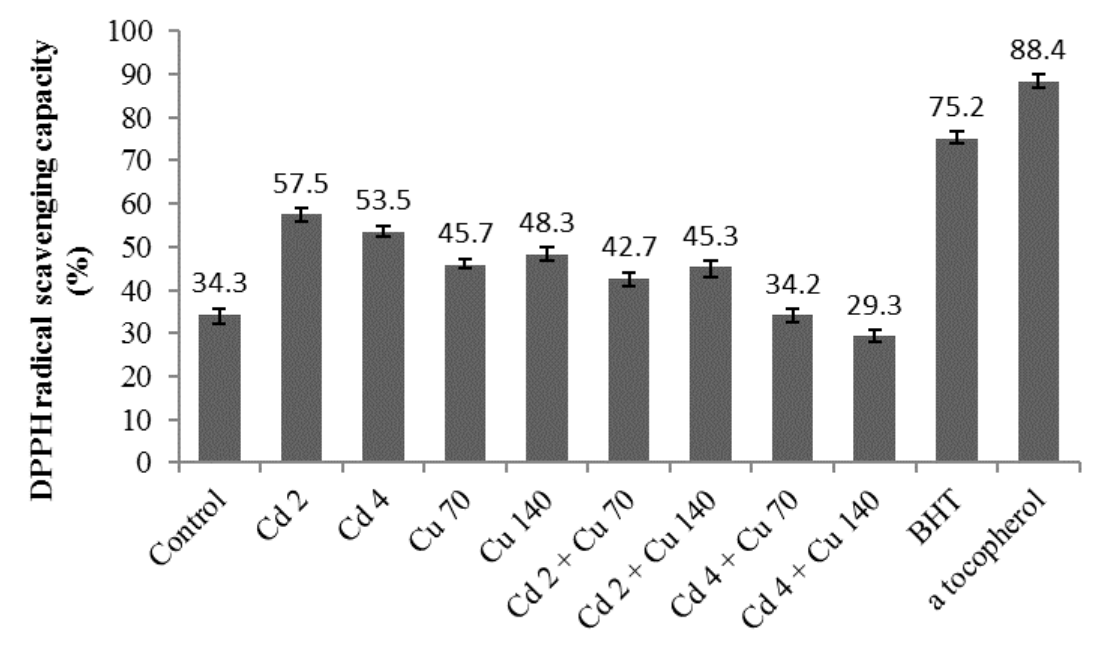

Figure 2. The impact of cadmium and copper on DPPH radical scavenging activity of G. procumbens. Bars represents standard error of differences between the means. $\mathrm{N}=15 . \mathrm{Cd} 2=$ cadmium $2 \mathrm{mg} / \mathrm{L} ; \mathrm{Cd} 4$ = cadmium $4 \mathrm{mg} / \mathrm{L} ; \mathrm{Cu} 70=$ copper $70 \mathrm{mg} / \mathrm{L} ; \mathrm{Cu} 140=$ copper $140 \mathrm{mg} / \mathrm{L} ; \mathrm{Cd} 2+\mathrm{Cu} 70=$ cadmium $2 \mathrm{mg} / \mathrm{L}+$ copper $70 \mathrm{mg} / \mathrm{L} ; \mathrm{Cd} 2+\mathrm{Cu} 140=$ cadmium $2 \mathrm{mg} / \mathrm{L}+$ copper $140 \mathrm{mg} / \mathrm{L} ; \mathrm{Cd} 4+\mathrm{Cu} 70=$ cadmium $4 \mathrm{mg} / \mathrm{L}+$ copper $70 \mathrm{mg} / \mathrm{L} ; \mathrm{Cd} 4+\mathrm{Cu} 140=$ cadmium $4 \mathrm{mg} / \mathrm{L}+$ copper $140 \mathrm{mg} / \mathrm{L}$.

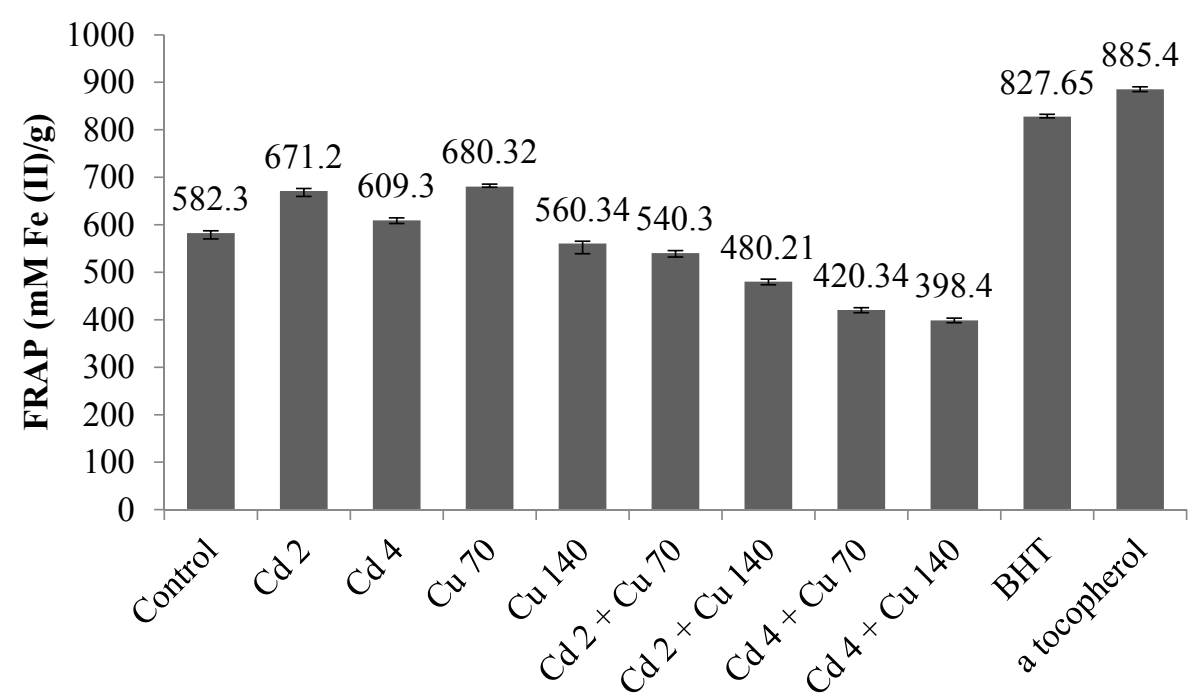

Figure 3. The impact of cadmium and copper on FRAP activity of G. procumbens. Bars represents standard error of differences between the means. $\mathrm{N}=15 . \mathrm{Cd} 2=$ cadmium $2 \mathrm{mg} / \mathrm{L} ; \mathrm{Cd} 4=$ cadmium $4 \mathrm{mg} / \mathrm{L} ; \mathrm{Cu} 70=$ copper $70 \mathrm{mg} / \mathrm{L} ; \mathrm{Cu} 140=$ copper $140 \mathrm{mg} / \mathrm{L} ; \mathrm{Cd} 2+\mathrm{Cu} 70=$ cadmium $2 \mathrm{mg} / \mathrm{L}+$ copper $70 \mathrm{mg} / \mathrm{L} ; \mathrm{Cd} 2+\mathrm{Cu} 140=$ cadmium $2 \mathrm{mg} / \mathrm{L}+$ copper $140 \mathrm{mg} / \mathrm{L} ; \mathrm{Cd} 4+\mathrm{Cu} 70=$ cadmium $4 \mathrm{mg} / \mathrm{L}+$ copper $70 \mathrm{mg} / \mathrm{L} ; \mathrm{Cd} 4+\mathrm{Cu} 140=$ cadmium $4 \mathrm{mg} / \mathrm{L}+$ copper $140 \mathrm{mg} / \mathrm{L}$. 


\section{Materials and Methods}

\subsection{Experimental Location, Plant Materials and Treatments}

This experiment was carried out at the Biology Department Greenhouse Complex, Universiti Putra Malaysia. Stem cuttings of G. procumbens (Lour.) Merr were propagated for two weeks in small pots and then transferred to pots filled with a soil-less mixture of burnt rice husk and coco peat in the ratio of 3:1. For fertilization, to each pot, 50\% Hoaglands nutrient solution was added once a week. Concentrations of heavy metals (100 mL per pot) in the form of $\mathrm{CdCl}_{2}(2,4 \mathrm{mg} / \mathrm{L}) ; \mathrm{CuSO} 4$ $(70,140 \mathrm{mg} / \mathrm{L})$ and combinations of $\mathrm{Cd}$ and $\mathrm{Cu}(\mathrm{Cd} 2: \mathrm{Cu} 70, \mathrm{Cd} 2: \mathrm{Cu} \mathrm{140,Cd} \mathrm{4:Cu} 70$ and Cd 4:Cu 140) were added once a week until end of experiment. Hoaglands solution (50\%) was used for the control treatment. The experiment was terminated after 12 weeks. The experiment was organized in a randomized complete block (RCBD) design with three replications. Each experimental unit contained of five seedlings, and there were a total of 135 seedlings used in the research. The microclimatic condition under the glasshouse are presented in Table 6.

Table 6. Microclimatic condition under the research area during experiments.

\begin{tabular}{cc}
\hline Microclimate Parameters & Quantification \\
\hline Relative humidity & $57.25-66.34 \%$ \\
Light intensity & $120-1630 \mu \mathrm{mol} / \mathrm{m}^{2} / \mathrm{s}$ \\
Day temperature & $29-34{ }^{\circ} \mathrm{C}$ \\
Night temperature & $18-23^{\circ} \mathrm{C}$ \\
Ambient $\mathrm{CO}_{2}$ & $382.56 \mu \mathrm{mol} / \mathrm{mol}$ \\
\hline
\end{tabular}

\subsection{Determination of Plant Biomass, Leaf Area and Basal Diameter}

Total plant biomass was taken by mixing the dry weight of root, stems and leaves per seedling. The plant parts were stored in paper bags and oven dried at $80{ }^{\circ} \mathrm{C}$ until constant weight was reached. Leaf area per plant was measured using a plant leaf area meter (LI-3100, LICOR Biosciecne, Lincoln, NB, USA). Basal diameter was determined by using Vernier callipers.

\subsection{Determination of Total Phenolics and Flavonoids}

The method used for extraction and quantification of total phenolics and flavonoids was as described by Ibrahim and Jaafar [52]. Ground leaves tissue samples $(0.1 \mathrm{~g})$ were extracted with $80 \%$ ethanol $(10 \mathrm{~mL})$ on an orbital shaker for $120 \mathrm{~min}$ at $50{ }^{\circ} \mathrm{C}$. The mixture was subsequently filtered (Whatman ${ }^{\mathrm{TM}}$ No.1, Maidstone, UK), and the filtrate was used for the quantification of total phenolics and total flavonoids. Folin-Ciocalteu reagent (Kanto Chemical, Osaka, Japan; diluted 10-fold) was used to determine the total phenolics content of the leaf samples. Two hundred $\mu \mathrm{L}$ of the sample extract was mixed with Follin-Ciocalteau reagent $(1.5 \mathrm{~mL})$ and allowed to stand at $22{ }^{\circ} \mathrm{C}$ for 5 min before adding $\mathrm{NaNO}_{3}$ solution (Ajax Finechem; New South Wales, Australia, $1.5 \mathrm{~mL}, 60 \mathrm{~g} \mathrm{~L}{ }^{-1}$ ). After two hours at $22{ }^{\circ} \mathrm{C}$, absorbance was measured at $725 \mathrm{~nm}$. The results were expressed as $\mathrm{mg} \mathrm{g}^{-1}$ gallic acid equivalent (Merck, Darmstadt, Germany; mg GAE $\mathrm{g}^{-1}$ dry sample). For total flavonoids determination, samples $(1 \mathrm{~mL})$ were mixed with $\mathrm{NaNO}_{3}(0.3 \mathrm{~mL})$ in a test tube covered with aluminium foil and left to stand for $5 \mathrm{~min}$. Then $10 \% \mathrm{AlCl}_{3}$ (Ajax Finechem; $0.3 \mathrm{~mL}$ ) was added followed by addition of $1 \mathrm{M}$ $\mathrm{NaOH}$ (Ajax Finechem; $2 \mathrm{~mL}$ ). The absorbance was measured at $510 \mathrm{~nm}$ using a spectrophotometer with rutin as a standard (results expressed as $\mathrm{mg} / \mathrm{g}$ rutin dry sample).

\subsection{Total Saponin Content}

Total saponin content was determined in leaves using vanillin-sulfuric acid colorimetric reaction by Makkar et al. [53]. The standard used for saponin is diosgenin (Merck). 


\subsection{Cadmium and Copper Analysis}

To measure $\mathrm{Cd}$ and $\mathrm{Cu}$ concentration, one gram of dried plant material samples (shoot and root separately; oven dried at $80{ }^{\circ} \mathrm{C}$ ) was digested in nitric acid (Kanto Chemical, Tokyo, Japan; $\mathrm{HNO}_{3}$; $65 \%$ ). Cadmium and copper concentration of the extracted solution was measured using an inductively coupled plasma emission (ICP-MS, 7500, Agilent, San Clara, CA, USA).

\subsection{Chlorophyll Measurement}

For the measurement of chlorophyll concentration, weighed fresh leaves $(200 \mathrm{mg})$ were grinded using a mortar and pestle and immersed in $10 \mathrm{~mL}$ of $100 \%$ acetone. Samples then homogenized with the B-Braun type homogenizer (Labequip, Markam, ON, Canada) at $1000 \mathrm{rpm}$ for one minute. The homogenate was filtered through two layer of cheesecloth, and was centrifuged at $2500 \mathrm{rpm}$ for $10 \mathrm{~min}$. The supernatant was separated and placed in quartz cuvettes and absorbance measured against a blank of 100\% acetone at 2 wavelengths. The two wavelengths of $662 \mathrm{~nm}$ and $645 \mathrm{~nm}$ were used as the peak absorbences of chlorophyll-a and chlorophyll-b. The total amount of chlorophyll-a and chlorophyll-b were then calculated according to the formulas of Lichtentaler and Wellburn [54].

\subsection{Antibacterial Activity}

Bacterial strains from four species of bacteria (Gram positive and Gram negative) were used. The Gram positive bacteria were Bacillus subtilis B 14512 and Staphylococcus aureus S15923. The Gram negative bacteria include Escherichia coli E 256 and Klebsiella pneumoniae K356 that were obtained from the Institute for Medical Research Malaysia. All bacteria were cultured on nutrient agar. The antibacterial assay was performed using disc diffusion (Kirby-Bauer) method. The density of bacteria was standardized using McFarland 0.5 turbidity standard and was swabbed onto Mueller Hinton Agar (Sigma-Aldrich; St. Louis, MO, USA) surface. One mg of leaves crude extract was dissolved initially in $100 \mu \mathrm{L}$ methanol and loaded onto sterile Whatman No. 1 filter paper discs $(6 \mathrm{~mm}$ diameter) and the discs were impregnated onto inoculated agar. The plates were left at $4{ }^{\circ} \mathrm{C}$ for an hour to allow the diffusion of extracts before they were incubated for $16-20 \mathrm{~h}$ at $37^{\circ} \mathrm{C}$. Antibacterial activities was indicated when clear inhibition zones were noted around the discs. Nyastatin (Oxoid; Chicago, IL, USA) at $10 \mu \mathrm{g} / \mathrm{mL}$ was used as a positive control. The diameter of the inhibition zones was measured and the results were expressed as mean of three independent experiments. The test was repeated three times [55].

\subsection{Phenylalanine Ammonia-Lyase (PAL) Activity}

Phenylalanine-ammonia-lyase (PAL) activity was measured using the method described by Martinez and Lafuante [56]. The enzyme activity was determined by spectrophotometrically measuring the production of trans-cinnamic acid from L-phenylalanine. Enzyme extract $(10 \mu \mathrm{L})$ was incubated at $40{ }^{\circ} \mathrm{C}$ with $12.1 \mathrm{mM}$ L-phenylalanine ( $90 \mu \mathrm{L}$, Sigma; St Louis, MS, USA) that was prepared in $50 \mathrm{mM}$ Tris- $\mathrm{HCl}$, (pH 8.5). After $15 \mathrm{~min}$ of reaction, trans-cinnamic acid yield was estimated by measuring increase in the absorbance at $290 \mathrm{~nm}$. The standard curve was prepared by using a trans-cinnamic acid standard (Sigma) and the PAL activity was expressed as $\mathrm{nM}$ trans-cinnamic acid/ $\mu \mathrm{g}$ protein $/ \mathrm{h}$.

\subsection{DPPH Radical Scavenging Assay}

The DPPH free radical scavenging activity of each sample was determined according to the method described by Mensor et al. [57]. A solution of $0.1 \mathrm{mM} \mathrm{DPPH}$ in methanol was prepared. The initial absorbance of the DPPH in methanol was measured at $515 \mathrm{~nm}$. An aliquot $(40 \mu \mathrm{L})$ of an extract was added to $3 \mathrm{~mL}$ of methanolic DPPH solution. The change in absorbance at $515 \mathrm{~nm}$ was measured after $30 \mathrm{~min}$. The antiradical activity (AA) was determined using the following formula: AA $\%=100-[($ Abs: sample - Abs: empty sample $)] \times 100) /$ Abs: control the optic density of the samples, the control and the empty samples were measured in comparison with methanol. 
A synthetic antioxidant, BHT (butylated hydroxytoluene; Sigma) and $\alpha$-tocopherol (Sigma), were used as positive controls.

\subsection{Reducing Ability (FRAP Assay)}

The ability to reduce ferric ions was measured using modifying methods of Benzie and Strain [58]. An aliquot $(200 \mu \mathrm{L})$ of the extract with appropriate dilution was added to $3 \mathrm{~mL}$ of FRAP reagent (Ajax, Berlin, Germany; 10 parts of $300 \mathrm{mM}$ sodium acetate buffer (Sigma) at pH 3.6, 1 part of $10 \mathrm{mM} \mathrm{TPTZ}$ solution and 1 part of $20 \mathrm{mM} \mathrm{FeCl}_{3} \cdot 6 \mathrm{H}_{2} \mathrm{O}$ solution) and the reaction mixture was incubated in a water bath at $37^{\circ} \mathrm{C}$. The increase in absorbance at $593 \mathrm{~nm}$ was measured after $30 \mathrm{~min}$. The antioxidant capacity based on the ability to reduce ferric ions of the extract was expressed as expressed in $\mu \mathrm{M}$ $\mathrm{Fe}(\mathrm{II}) / \mathrm{g}$ dry mass and compared with those of standards for BHT (Sigma), ascorbic acid (Sigma), and $\alpha$-tocopherol (Ajax).

\subsection{Statistical Analysis}

Data were analysed using analysis of variance using SAS version 17 (SAS institute, Carry, NC, USA). Mean separation test between treatments was performed using Duncan multiple range test and standard error of differences between means was calculated with the assumption that data were normally distributed and equally replicated.

\section{Conclusions}

This study was devoted to determining the effects of $\mathrm{Cd}$ and $\mathrm{Cu}$ on the growth, heavy metal bioaccumulation and biochemical changes in the medicinal plant G. procumbens to predict the effect on the efficacy of this plant. It was found that combined $\mathrm{Cd}$ and $\mathrm{Cu}$ treatment had the greatest influence on the growth, heavy metal accumulation and biochemical changes in G. procumbens. Cadmium and copper exposure reduced the plant growth which was indicated by a reduction in total plant dry weight, leaf area and basal diameter. The reduction of total chlorophyll content was observed in all treatments except control indicating that G. procumbens was under stress conditions when exposed to the heavy metals. The accumulation of heavy metals in shoot and root was higher than the rate recommended by the $\mathrm{WHO}$ or consumer exposure to heavy metal contamination when consumed. The combined heavy metal exposure $(\mathrm{Cd}+\mathrm{Cu})$ has shown to reduce the efficacy of this herbal plant, reducing the production of total phenolics, total flavonoids, saponins, antibacterial, DPPH and FRAP activity compared to single exposure to $\mathrm{Cd}$ or $\mathrm{Cu}$. Although the antioxidant and antimicrobial activity was highest under single heavy metal treatment, the heavy metal content of $\mathrm{Cd}$ and $\mathrm{Cu}$ exceeded the safety level recommended by the WHO indicating that G. procumbens planted in contaminated soil is not safe for consumption. In future work the study of the interaction effects of other heavy metals such as lead, zinc, and chromium is suggested to understand the impact of these heavy metal interactions on the efficacy of medicinal plants.

Acknowledgments: The authors would like to thank from all staff of the Laboratory of Plant Physiology, Department of Biology, Faculty of Sciences, Universiti Putra Malaysia for all their help and guidance in order to accomplish this project.

Author Contributions: Study design and experimental work was by Mohd Hafiz Ibrahim The first draft of the paper was written by Mohd Hafiz Ibrahim and reviewed by Yap Chee Kong and Nurul Amalina Mohd Zain participated in antioxidant experiment and data collection. All authors reviewed and approved the final version.

Conflicts of Interest: The authors declare no conflict of interest. The founding sponsors had no role in the design of the study; in the collection, analyses, or interpretation of data; in the writing of the manuscript, and in the decision to publish the results.

\section{References}

1. Aery, N.C.; Rana, D.K. Interactive effects of Zn, Pb and Cd in barley. J. Environ. Sci. Eng. 2007, 49, 71-76. [PubMed] 
2. An, Y.J.; Kim, Y.M.; Kwon, T.I.; Jeong, S.W. Combined effect of copper, cadmium, and lead upon Cucumis sativus growth and bioaccumulation. Sci. Total Environ. 2004, 326, 85-93. [CrossRef] [PubMed]

3. Mishra, S.; Srivastava, S.; Tripathi, R.D.; Govindarajan, R.; Kuriakose, S.V.; Prasad, M.N.V. Phytochelatin synthesis and response of antioxidants during cadmium stress in Bacopa monnieri L. Plant Physiol. Biochem. 2006, 44, 25-37. [CrossRef] [PubMed]

4. Broadley, M.R.; White, P.J.; Hammond, J.P.; Zelko, I.; Lux, A. Zinc in plants. New Phytol. 2007, 173, 677-679. [CrossRef] [PubMed]

5. Brumbarova, T.; Bauer, P.; Ivanov, R. Molecular mechanisms governing Arabidopsis iron uptake. Trends Plant Sci. 2015, 20, 124-133. [CrossRef] [PubMed]

6. Dubey, S.; Shri, M.; Misra, P.; Lakhwani, D.; Bag, S.K.; Asif, M.H.; Trivedi, P.K.; Tripathi, R.D.; Chakrabarty, D. Heavy metals induce oxidative stress and genome-wide modulation in transcriptome of rice root. Funct. Integr. Genom. 2014, 14, 401-417. [CrossRef] [PubMed]

7. Aibibu, N.; Liu, Y.G.; Zeng, G.M.; Wang, X.; Chen, B.B.; Song, H.X.; Xu, L. Cadmium accumulation in Vetiveria zizanioides and its effects on growth, physiological and biochemical characters. Bioresour. Technol. 2010, 101, 6297-6307. [CrossRef] [PubMed]

8. Das, P.; Samantaray, S.; Rout, G.R. Studies on cadmium toxicity in plants: A review. Environ. Pollut. 1997, 98, 29-36. [CrossRef]

9. Yruela, I. Copper in plants. Braz. J. Plant. Physiol. 2005, 17, 145-146. [CrossRef]

10. Callow, M.E.; Callow, J. Marine biofouling: A sticking problem. Biologist 2002, 49, 1-5.

11. Kocasoy, G.; Sahin, V. Heavy metal removal from industrial wastewater by clinoptilolite. J. Environ. Sci. Health Part A 2007, 42, 2139-2146. [CrossRef] [PubMed]

12. Gill, S.S.; Tuteja, N. Reactive oxygen species and antioxidant machinery in abiotic stress tolerance in crop plants. Plant Physiol. Biochem. 2010, 48, 909-930. [CrossRef] [PubMed]

13. Na, G.N.; Salt, D.E. The role of sulfur assimilation and sulfur containing compounds in trace element homeostasis in plants. Environ. Exp. Bot. 2010, 72, 18-25. [CrossRef]

14. Nakano, Y.; Asada, K. Hydrogen peroxide is scavenged by ascorbate-specific peroxidase in spinach chloroplasts. Plant Cell Physiol. 1981, 22, 867-880.

15. Nouairi, I.; Ben, A.W.; Ben, Y.N.; Ben, M.D.D.; Ghorbal, M.H.; Zarrouk, M. Antioxidant defense system in leaves of Indian mustard (Brassica juncea) and rape (Brassica napus) under cadmium stress. Acta Physiol. Plant. 2009, 31, 237-247. [CrossRef]

16. Oueslati, S.; Ksouri, R.; Pichette, A.; Lavoie, S.; Girard-Lalancette, K.; Mshvildadze, V.; Abdelly, C.; Legault, J. A new flavonol glycoside from the medicinal halophyte Suaeda fruticosa. Nat. Prod. Res. 2014, 28,960-966. [CrossRef] [PubMed]

17. Perry, L.M. Medicinal Plants of East and South East Asia; MIT Press: Cambridge, MA, USA, 1980.

18. Wiart, C. Medicinal Plants of the Asia-Pacific: Drugs for the Future? World Scientific: Singapore, 2006; pp. 756-766.

19. Jenie, R.I.; Meiyanto, E. Co-chemotherapy of sambung nyawa (Gynura procumbens (Lour.) Merr.) leaves ethanolic extract and doxorubicin on breast cancer cell. Maj. Pharm. Indones. 2007, 18, 81-87.

20. Ong, G.H.; Wong, L.S.; Tan, A.L.; Yap, C.K. Effects of metal-contaminated soils on the accumulation of heavy metals in gotu kola (Centella asiatica) and the potential health risks: A study in Peninsular Malaysia. Environ. Monit. Assess. 2016, 188, 40. [CrossRef] [PubMed]

21. Puangpronpitag, D.; Chaichanadee, S.; Naowaratwattana, W.; Sittiwet, C.; Thammasarn, K. Evaluation of nutritional value and antioxidative properties of the medicinal plant Gynura procumbens extract. Asian J. Plant Sci. 2010, 9, 146-151.

22. Iskander, M.N.; Song, Y.; Coupar, I.M.; Jiratchariyakul, W. Antiinflammatory screening of the medicinal plant Gynura procumbens. Plant Foods Hum. Nutr. 2002, 57, 233-244. [CrossRef] [PubMed]

23. Zhang, X.F.; Tan, B.K. Effects of an ethanolic extract of Gynura procumbens on serum glucose, cholesterol and triglyceride levels in normal and streptozotoc in induced diabetic rats. Singap. Med. J. 2000, 41, 9-13.

24. Hew, C.S.; Gam, L.H. Proteome analysis of abundant proteins extracted from the leaf of Gynura procumbens (Lour.) Merr. Appl. Biochem. Biotechbol. 2010, 165, 1577-1586. [CrossRef] [PubMed]

25. Patrick, D.S.; Claudia, C.; Roberto, T.; Giuseppe, P.; Erika, D.I.; Bruno, P. A quick screening to assess the phytoextraction potential of cadmium and copper in Quercus pubescens plantlets. IForest 2017, 10, 93-98. 
26. Deng, B.; Yang, K.; Zhang, Y.; Li, Z. Can heavy metal pollution defend seed germination against heat stress? Effect of heavy metals $(\mathrm{Cu} 2+, \mathrm{Cd} 2+$ and $\mathrm{Hg} 2+)$ on maize seed germination under high temperature. Environ. Pollut. 2016, 216, 46-55. [CrossRef] [PubMed]

27. Versieren, L.; Evers, S.; AbdElgawad, H.; Asard, H.; Smolders, E. Mixture toxicity of copper, cadmium, and zinc to barley seedlings is not explained by antioxidant and oxidative stress biomarkers. Environ. Toxicol. Chem. 2017, 36, 220-230. [CrossRef] [PubMed]

28. Dresler, S.; Hanaka, A.; Bednarek, W.; Maksymiec, W. Accumulation of low-molecular-weight organic acids in roots and leaf segments of Zea mays plants treated with cadmium and copper. Acta Physiol. Plant. 2014, 36, 1565-1575. [CrossRef]

29. Doğanlar, Z.B. Metal accumulation and physiological responses induced by copper and cadmium in Lemna gibba, L. minor and Spirodela polyrhiza. Chem. Speciat. Bioavailab. 2013, 25, 79-88. [CrossRef]

30. Tuna, A.L.; Yildiztekin, M.; Köşkeroglu, S.; Yokaş, I.; Kaya, C. Maize (Zea mays L) plant responses to excess copper, cadmium, cobalt, lead and chromium. Fresenius Environ. Bull. 2014, 24, 3996-4006.

31. Jansen, S.; Broadley, M.R.; Robbrecht, E.; Smets, E. Aluminium hyper accumulation in angiosperms: A review of its phylogenetic significance. Bot. Rev. 2002, 68, 235-269. [CrossRef]

32. World Health Organization. WHO Guidelines for Assessing Quality of Herbal Medicines with Reference to Contaminants and Residue (Geneva); WHO: Geneva, Switzerland, 2007; pp. 321-333.

33. Takeya, I.; Etsuko, K.; Yasushi, S.; Mirei, U.; Mitsuhiro, O.; Hideaki, N.; Koji, N. Estimation of cumulative cadmium intake causing Itai-itai disease. Toxicol. Lett. 2005, 159, 192-201.

34. Lakhdar, A.; Falleh, H.; Ouni, Y.; Ksouri, R.; Abdelly, C. Municipal solid waste compost application improves productivity, polyphenol content, and antioxidant capacity of Mesembryanthemum edule. J. Hazard. Mater. 2011, 191, 373-379. [CrossRef] [PubMed]

35. Okem, A.; Stirk, W.A.; Street, R.A.; Southway, C.; Finnie, J.F.; Van Staden, J. Effects of Cd and Al stress on secondary metabolites, antioxidant and antibacterial activity of Hypoxis hemerocallidea Fisch. \& C.A. Mey. Plant Physiol. Biochem. 2015, 97, 147-155. [PubMed]

36. Hostettmann, K.; Marston, A. Saponins; Cambridge University Press: Cambridge, UK, 1995 ; p. 18. ISBN 0-521-32970.

37. Jagadeesan, J.; Nandakumar, N.; Rengarajan, T.; Balasubramanian, M.P. Diosgenin, a steroidal saponin, exhibits anticancer activity by attenuating lipid peroxidation via enhancing antioxidant defense system during NMU-induced breast carcinoma. J. Environ. Pathol. Toxicol. Oncol. 2012, 31, 121-129. [CrossRef] [PubMed]

38. Bertrand, L.; Pascale, V.S.; Cecile, C.; Jean, L.C.; Jean, L.B. Diosgenin, a plant steroid, induces apoptosis in human rheumatoid arthritis synoviocytes with cyclooxygenase-2 overexpression. Arthritis Res. Ther. 2004, 6, 373-383.

39. Irma, P.; Agnieszka, G.; Danuta, S. Saponins as cytotoxic agents: A review. Phytochem. Rev. 2010, 9, $425-474$.

40. Okema, A.; Southwayb, C.; Stirka, W.A.; Streetc, F.A.; Finniea, J.F.; Van Stadena, J. Effect of cadmium and aluminium on growth, metabolite content and biological activity in Drimia elata(Jacq.) Hyacinthaceae. S. Afr. J. Bot. 2015, 98, 142-147. [CrossRef]

41. Duraipandiyan, V.; Ayyanar, M.; Ignacimuthu, S. Antimicrobial activity of some ethnomedicinal plants used by Paliyar tribe from Tamil Nadu, India. BMC Complement. Altern. Med. 2006, 6, 35. [CrossRef] [PubMed]

42. Prasad, R.N.; Viswanathan, S.; Renuka, D.; Nayak, V.; Swetha, V.C.; Archana, B.R.; Parathasarathy, N.; Rajkumar, J. Preliminary phytochemical screening and antimicrobial activity of Samanea saman. J. Med. Plants Res. 2008, 2, 268-270.

43. Margna, U.; Margna, E.; Vainjarv, T. Influence of nitrogen nutrition on the utilization of L-phenylalanine for building flavonoids in buckwheat seedling tissue. J. Plant Physiol. 1989, 134, 697-702. [CrossRef]

44. Kováčik, J.; Bačkor, M.; Kaduková, J. Physiological responses of Matricaria chamomilla to cadmium and copper excess. Environ. Toxicol. 2008, 23, 123-130. [CrossRef] [PubMed]

45. Jozef, K.; Bořivoj, K.; Josef, H.; František, Š.; Martin, B. Comparison of cadmium and copper effect on phenolic metabolism, mineral nutrients and stress-related parameters in Matricaria chamomilla plants. Plant Soil. 2009, 320, 231. [CrossRef]

46. Kleckerova, A.; Sobrova, P.; Krystofova, O.; Sochor, J.; Zitka, O.; Babula, P.; Adam, V.; Docekalova, H.; Kizek, R. Cadmium (II) and zinc (II) ions effects on maize plants revealed by spectroscopy and electrochemistry. Int. J. Electrochem. Sci. 2011, 12, 6011-6031. 
47. Dumas, Y.; Dadomo, M.; Di Lucca, G.; Grolier, P. Effects of environmental factors and agricultural techniques on antioxidant content of tomatoes. J. Sci. Food Agric. 2003, 83, 369-382. [CrossRef]

48. Kader, A.A.; Rolle, R.S. The Role of Post-Harvest Management in Assuring the Quality and Safety of Horticultural Produce; Food and Agriculture Organization of the United Nations: Rome, Italy, 2004; p. 152.

49. Dudonne, S.; Vitrac, X.; Coutiere, P.; Woillez, M.; Mérillon, J.M. Comparative study of antioxidant properties and total phenolic content of 30 plant extracts of industrial interest using DPPH, ABTS, FRAP, SOD, and ORAC assays. J. Agric. Food Chem. 2009, 57, 1768-1774. [CrossRef] [PubMed]

50. Kumar, V.A.; Mohan, T.K.; Murugan, K. Purification and kinetic characterization of polyphenol oxidase from Barbados cherry (Malpighia glabra L.). Food Chem. 2008, 110, 328-333. [CrossRef] [PubMed]

51. Turumtay, E.A.; İslamoğlu, F.; Çavuş, D.; Şahin, H.; Turumtay, H.; Vanholme, B. Correlation between phenolic compounds and antioxidant activity of Anzer tea (Thymus praecox Opiz subsp. caucasicus var. caucasicus). Ind. Crop Prod. 2014, 52, 687-694. [CrossRef]

52. Ibrahim, M.H.; Jaafar, H.Z.E. The influence of carbohydrate, protein and phenylanine ammonia lyase on up-regulation of production of secondary metabolites (Total phenolics and flavonoid) in Labisia pumila (Blume) fern-vill (Kacip Fatimah) under high $\mathrm{CO}_{2}$ and different nitrogen levels. Molecules 2011, 16, 4172-4190. [CrossRef]

53. Makkar, H.P.S.; Siddhuraju, S.; Siddhuraju, P.; Becker, K. Plant Secondary Metabolites; Humana Press: Totowa, NJ, USA, 2007.

54. Lichtenthaler, H.K.; Wellburn, A.R. Determination of Total Carotenoids and Chlorophylls A and B of Leaf in Different Solvents. Biochem. Soc. Trans. 1985, 11, 591-592. [CrossRef]

55. Boussaada, O.; Chriaa, J.; Nabli, R.; Ammar, S.; Saidana, D.; Mahjoub, M.A.; Chraeif, I.; Helal, A.N.; Mighri, Z. Antimicrobial and antioxidant activities of methanol extracts of Evax pygmaea (Asteraceae) growing wild in Tunisia. World J. Microbiol. Biotechnol. 2008, 24, 1289-1296. [CrossRef]

56. Martínez-Téllez, M.A.; Lafuénte, M.T. Effects of high temperature conditioning on ethylene, phenylalanine ammonia lyase, peroxidase and polyphenol oxidase in flavedo of chilled "Fortune" mandarin fruit. J. Plant Physiol. 1997, 150, 674-678. [CrossRef]

57. Mensor, L.L.; Menezes, F.S.; Leitao, G.G.; Reis, A.S.; Santos, T.S.; Coube, C.S. Screening of Brazilian plant extracts for antioxidant activity by the use of DPPH free radical method. Phytother. Res. 2001, 15, 127-130. [CrossRef] [PubMed]

58. Benzie, I.F.F.; Strain, J.J. The ferric reducing ability of plasma (FRAP) as a measure of 'Antioxidant Power': The FRAP assay. Anal. Biochem. 1996, 239, 70-76. [CrossRef] [PubMed]

Sample Availability: Not available.

(C) 2017 by the authors. Licensee MDPI, Basel, Switzerland. This article is an open access article distributed under the terms and conditions of the Creative Commons Attribution (CC BY) license (http://creativecommons.org/licenses/by/4.0/). 